\title{
Experimental challenge and clinical cases of Bohle iridovirus (BIV) in native Australian anurans
}

\author{
B. R. Cullen*, L. Owens \\ Microbiology and Immunology, James Cook University, Townsville, Queensland 4811, Australia
}

\begin{abstract}
Ranaviruses have been observed with increasing frequency amongst poikilothermic vertebrate hosts. The impact of ranaviruses upon amphibian populations has remained largely unknown. A gene probe for Bohle iridovirus (BIV) based upon primers designed to detect epizootic haematopoietic necrosis virus (EHNV) was constructed. A PCR and dot-blot system was used successfully in screening for the presence of BIV nucleic acid in digested formalin-fixed, paraffinembedded amphibian tissues. Juvenile frogs were more susceptible to BIV than adults. In experimental challenges and epizootics in captive frogs, juvenile Litoria caerulea, L. alboguttata, Cyclorana brevipes and Pseudophryne coriacea were acutely susceptible. High mortality (at or near $100 \%$ ) resulted, usually occurring within 5 to $25 \mathrm{~d}$ depending on dose and method of exposure. Histopathological changes included mainly hepatic, renal and splenic necroses. Significant haemosiderosis was encountered in more chronically infected frogs. BIV could be reisolated from juvenile L. caerulea $>40 \mathrm{~d}$ after inoculation, and $>200 \mathrm{~d}$ after the first mortalities occurred in an epizootic in L. alboguttata. Adult L. rubella, L. inermis, L. caerulea, Cophixalus ornatus and Taudactylus acutirostris were less susceptible in trials ranging from 30 to $>100 \mathrm{~d}$. There was some evidence of chronic infection, and BIV could be detected by PCR. Wild moribund adult $L$. caerulea from Townsville and captive juvenile Pseudophryne corieacea from Sydney undergoing mortality tested positive with the BIV PCR. PCR and dot blot was more sensitive than viral isolation. PCR could detect BIV in amphibians long after BIV challenge, and in amphibians which appeared healthy. Ranaviruses could be having an impact on Australian herpetofauna.
\end{abstract}

KEY WORDS: Ranavirus · Iridovirus · Amphibian mortality $\cdot$ Decline $\cdot$ Amphibian disease Resale or republication not permitted without written consent of the publisher

\section{INTRODUCTION}

Bohle iridovirus (BIV) was isolated from metamorphs of the ornate burrowing frog Limnodynastes ornatus collected at a temporary pond near Townsville, Australia. It was associated with mortalities in these captive amphibians during or soon after metamorphosis (Speare \& Smith 1992).

Frog virus 3 (FV3) is the type species for the genus Ranavirus within the family Iridoviridae. FV3 was isolated in 1965 from renal adenocarcinoma of the leopard frog Rana pipiens, but was later found to bare no causal relationship to the tumour (Granoff 1989). Simi-

*E-mail: bradford.cullen@jcu.edu.au lar amphibian ranaviruses have been isolated from normal and diseased adult leopard frogs, normal adult and larval newts Triturus viridescens and diseased bullfrogs $R$. catesbeiana in North America (Clark et al. 1968, 1969, Essani \& Granoff 1989b). These viruses are very similar or identical, and are generally considered to be strains of the same Ranavirus type (Willis et al. 1985). Iridoviruses have been found more recently in the common frog $R$. temporaria in the United Kingdom (Drury et al. 1995, Cunningham et al. 1996), the cane toad Bufo marinus, and Leptodactylus spp. in Venezuela (Zupanovic et al. 1998), and tiger frogs R. tigrina in Thailand (Kanchanakhan 1998).

BIV is most probably a member of the Ranavirus genus. Closely related Ranavirus isolates have been found around the world from a variety of poikilother- 
mic hosts. Protein and restriction-enzyme digest patterns of the following vertebrate iridoviruses were similar, indicating that they are more closely related to the Ranavirus genus than to any other genera of the Iridoviridae: FV3, epizootic haematopoietic necrosis virus (EHNV), BIV, and iridoviruses of sheatfish Siluris glanis, catfish Ictalurus melas, doctor fish Labroides dimidatus, guppy Poecilia reticulata, box turtle Terrapene carolina, tortoise Agrionemys horsfieldi, tadpole Rana aurora and R. esculenta (Willis et al. 1977, Elliot \& Kelly 1980, Flugel et al. 1982, Essani \& Granoff 1989a,b, Eaton et al. 1991, Hedrick et al. 1992, Ahne 1994, Ahne et al. 1995, 1997, Cullen et al. 1995, Mao et al. 1997, Tapiovaara et al. 1998).

Ranaviruses in Australia and elsewhere could be impacting upon amphibian populations. The experimental determination of susceptible host species and pathology of BIV is important in the elucidation of potential hosts in the wild. Identification of disease pathology assists in the diagnosis of BIV in wild animals. Information concerning host-specificity and susceptibility aids in extrapolating possible impacts the virus may have on wild populations, as well as transmission and transportation potentialities.

Australian ranaviruses appear to be host non-specific, and may have a large host range among vertebrate poikilotherms. Experimentally, EHNV was able to infect a number of fish species, with some succumbing to an acute disease and others appearing relatively refractory (Langdon 1989). BIV has been found to cause disease in a number of amphibian (Speare \& Smith 1992, Cullen et al. 1995), piscine (Moody \& Owens 1994, Ariel \& Owens 1997) and reptilian (Ariel 1997) hosts.

Further experimental testing of BIV was desirable to extend the current knowledge on the range of potential amphibian hosts, disease dynamics, pathology and possible impacts on wild amphibian populations. Various wild-caught native frog species of different life history stages were subjected to BIV challenge. Histopathological, viral isolation and PCR techniques were utilised in the investigation. Some diseased native frogs caught from the wild were also examined to determine whether BIV was associated with the diseased state.

\section{MATERIALS AND METHODS}

Frogs. Litoria caerulea tadpoles were collected from a residential property at Cardwell, Queensland. Wild frogs had spawned in an unused aquarium at the residence in January 1995. Tadpoles were raised to metamorphosis, and the postmetamorphic juveniles were used in the viral challenge. L. alboguttata tadpoles were collected from a roadside ditch at Jensen, Townsville, Queensland in March 1994. Two juvenile Cyclorana brevipes were collected from Taylor's Beach, Queensland, and brought to the laboratory in March 1994. Adult L. caerulea were collected from suburban residences in Townsville, August 1993. Adult L. rubella were collected from Oonoonba, Townsville, Queensland in July 1995. Adult L. inermis were collected from the Gem Fields and Amber Station, Mount Surprise, Queensland in August 1995. Adult Cophixalus ornatus were collected from Atherton, Queensland in September 1993. Adult Taudactylus acutirostris were collected from Big Tableland, Queensland in September 1993.

Litoria caerulea tadpoles were raised at a pathogenfree facility in polystyrene boxes with gauze lids, $L$. alboguttata tadpoles were maintained in glass aquariums. Water was aerated, and tadpoles were fed boiled lettuce and a commercial flake fish food.

Post-metamorphic anurans were housed in a similar manner before and during viral challenge. Frogs were housed in clear plastic containers $21 \times 21 \times 8 \mathrm{~cm}$ (height) with gauze lids. They were fed live adult Drosophila sp., a dish of distilled water was provided, and some dried bark and leaves were added as hides. The large Litoria caerulea adults were initially housed in a plastic container $64 \times 39 \times 39 \mathrm{~cm}$ (height) with a screen lid and were fed a variety of live insects. Throughout the infection trial, the adult L. caerulea were housed in glass tanks $50 \times 22 \times 22 \mathrm{~cm}$ (height) Room temperature during housing of the frogs and experimental challenge ranged from 21 to $29^{\circ} \mathrm{C}$.

BIV experimental challenge. The BIV challenge experiments were undertaken over a number of years as the various frogs were collected and raised. In the bath challenge treatments, BIV was added to a dish containing distilled water at the specified dose (Table 1), and this was placed into the frog housing container. For the injection challenge, BIV was injected intraperitoneally at the specified dose (Table 1) using a 27 gauge needle on a $1 \mathrm{ml}$ syringe. For the adult Litoria caerulea, an inoculum of $500 \mu \mathrm{l}$ was used, for other frogs a $100 \mu$ inoculum was used. For contact challenge, uninoculated frogs were placed into the same housing container as the injected frogs. Control individuals were uninoculated, and housed separately but in the same manner as inoculated frogs.

Clinical cases. Litoria alboguttata tadpoles and juveniles, and Cyclorana brevipes juveniles were not intentionally challenged with BIV, but started undergoing mortality whilst being housed in the Aquatic Pathobiology experimental facility. An adult L. caerulea (snout-urostyle length $117 \mathrm{~mm}$ ) was collected from a residence in Cranbrook, Townsville, Queensland, in September 1995. It was emaciated and sluggish. It was 
Table 1. Regime for experimental challenges of native Australian amphibians with Bohle iridovirus (BIV)

\begin{tabular}{|llccc|}
\hline Species & $\begin{array}{l}\text { Challenge } \\
\text { treatment }\end{array}$ & $\mathrm{N}$ & $\begin{array}{c}\text { Dose } \\
\left(\mathrm{TCID}_{50} \mathrm{ml}^{-1}\right)\end{array}$ & $\begin{array}{c}\text { Frog length } \\
(\mathrm{mm})\end{array}$ \\
\hline Litoria caerulea & Bath & 18 & $10^{3}$ & $13-19$ \\
Juveniles & Injection low dose & 18 & $10^{3}$ & \\
& Injection high dose & 20 & $10^{4.5}$ & \\
Litoria caerulea & Control & 10 & $\mathrm{Nil}$ & \\
Adults & Bath & 4 & $10^{3}$ & $77-109$ \\
& Injection & 4 & $10^{3}$ & \\
Litoria rubella & Incontact & 4 & $\mathrm{Nil}$ & \\
Adults & Control & 3 & $\mathrm{Nil}$ & \\
Cophixalus ornatus & Injection & 2 & $10^{4.5}$ & $22-28$ \\
Adults & Control & 1 & $\mathrm{Nil}$ & \\
& Bath & 3 & $10^{3}$ & $15-21$ \\
Injection & 3 & $10^{3}$ & \\
Taudactylus acutirostris & Bath & 2 & $\mathrm{Nil}$ & \\
Adults & Injection & 2 & $\mathrm{Nil}$ & \\
& Control & 3 & $10^{3}$ & $18-20$ \\
& & 2 & $10^{3}$ & \\
\hline
\end{tabular}

and $25 \mathrm{~d}$ post-challenge in the injection and bath challenge treatments. In the incontact and control treatments, 1 frog was sacrificed 20 and 25 d post-challenge. Unless mortality occurred, 1 adult Taudactylus acutirostris from the injection and bath challenge treatments was sacrificed 15, 20 and 25 d post-challenge, and controls 20 and $25 \mathrm{~d}$ post-challenge. The frozen Pseudophryne coriacea juveniles were processed for histopathology and viral isolation, the juvenile Cyclorana brevipes carcasses were processed for viral isolation only.

Mortality data for amphibians experimentally challenged with BIV in this paper, in Cullen (2000) \& Cullen et al. (1995) was collated to obtain a comparison of mortality with the life history stage of the host. An odds ratio was calculated to determine the excess risk juveniles have of dying due to BIV exposure comsacrificed using chloroform and processed for virological examination. Pseudophryne corieacea tadpoles were collected from northern New South Wales in February 1994, and were housed at a Sydney residence. Juveniles started suffering mortality 8 mo later. Six whole frozen frogs were sent to James Cook University, where they were processed for virological examination. Snout-urostyle length ranged from 19 to $25 \mathrm{~mm}$.

Post-mortem evaluations. Litoria caerulea juveniles, L. rubella adults, L. inermis adults and L. alboguttata tadpoles and juveniles were observed regularly for signs of morbidity or mortality. Upon death, frogs were sectioned longitudinally. Half the frog was prepared for viral isolation, the other half for histopathology. At the end of the experiment, remaining live frogs were sacrificed using chloroform and processed in the same manner. If the frog carcass was in a decomposed state and not fit for histology, the whole frog was frozen for viral isolation.

One adult Litoria caerulea from each of the inject, incontact and bath treatments was killed with chloroform every $5 \mathrm{~d}$ commencing on the tenth day postchallenge; 1 control frog was killed every $5 \mathrm{~d}$ commencing 15 d post-challenge. Frogs were dissected, organs were removed and processed for viral isolation and histopathology. The moribund adult L. caerulea was treated similarly, but in addition a blood smear was made and stained with Giemsa.

Smaller frogs were halved longitudinally, with one half prepared for viral isolation and the other for histopathology. Unless mortality occurred, 1 adult Cophixalus ornatus was killed with chloroform 15, 20 pared to adults. The following BIV-exposed frogs were included in the calculation: Adults-Bufo marinus (30 frogs), Litoria rubella (2 frogs), L. inermis (2 frogs), L. caerulea (8 frogs), Cophixalus ornatus (6 frogs), Taudactylus acutirostris (6 frogs); juveniles-Bufo marinus (4 frogs), L. caerulea (56 frogs), L. latopalmata (2 frogs), Limnodynastes terraereginae (16 frogs).

Viral isolation. Tissue samples collected for isolation of BIV were placed into individual plastic storage bags and stored at $-20^{\circ} \mathrm{C}$ until processing. After thawing, samples were chopped and placed into a $1.5 \mathrm{ml}$ Eppendorf tube containing $600 \mu \mathrm{l}$ of Dulbecco's modified Eagle's Medium (DMEM). Samples were either ultrasonicated for $1 \mathrm{~min}$ at $8 \mu \mathrm{m}$ distance whilst on ice, or three $0.5 \mathrm{~mm}$ diameter glass beads were added to the tube which was then vortexed for 2 min at $4^{\circ} \mathrm{C}$. Cellular debris was then pelleted by centrifugation at $7000 \times g$ for $3 \mathrm{~min}$, in preparation for introduction to cell culture. BF-2 cells were cultured in each well of a 24 -well tissue culture plate, with each well containing $900 \mu \mathrm{l}$ of DMEM with $5 \%$ foetal bovine serum (FBS); $100 \mu \mathrm{l}$ of clarified sample was added to each well. The plate was incubated at $25^{\circ} \mathrm{C}$ in a humid, airtight, $\mathrm{CO}_{2}$ rich container, and checked daily for the onset of cytopathic effect (CPE). Samples were left for 2 passages of $14 \mathrm{~d}$ each before being declared negative.

Histological preparation. Tissues for histological examination were fixed in either $10 \%$ neutrally buffered formalin or Bouin's fixative for at least $48 \mathrm{~h}$, washed in $70 \%$ ethanol, embedded in paraffin and sectioned at a thickness of $5 \mu \mathrm{m}$. Tissues were stained in Mayer's haematoxylin and eosin (H\&E) and Perrl's Prussian blue stain, and observed under light microscopy. 
PCR and dot blot hybridisation. Paraffin embedded sections from Litoria rubella, $L$. inermis, the adult $L$. caerulea from Cranbrook and Pseudophryne coriacea were cut at a thickness of $5 \mu \mathrm{m}$ and 4 to 5 of these were placed into a clean, autoclaved $1.5 \mathrm{ml}$ Eppendorf tube. Between each block, the cutting blade was removed, dipped in xylene and flamed thoroughly, as were the handling forceps. To each tube we added $500 \mu \mathrm{l}$ of digestion buffer (10 mM Tris ( $\mathrm{pH} 7.4), 100 \mathrm{mM} \mathrm{NaCl}$, $25 \mathrm{mM}$ disodium EDTA, $0.5 \%$ sodium dodecyl sulphate [SDS]) with $200 \mathrm{\mu g} \mathrm{ml}^{-1}$ final concentration of proteinase K. Tubes were incubated overnight at $37^{\circ} \mathrm{C}$ on a mixer. Nucleic acid was extracted in an equal volume of phenol:chloroform:isoamyl alcohol (25:24:1), and then with an equal volume of chloroform. Nucleic acid was precipitated from the aqueous phase by the addition of $1 / 4$ volume of $8 \mathrm{M}$ ammonium acetate and an equal volume of isopropanol. This was incubated over 2 nights at $-20^{\circ} \mathrm{C}$. The precipitate was concentrated by centrifugation at $7000 \times g$ for 30 min at $4^{\circ} \mathrm{C}_{\text {; }}$ $500 \mu \mathrm{l}$ of cold $70 \%$ ethanol was added, then tubes were centrifuged again at $7000 \times g$ for $30 \mathrm{~min}$ at $4^{\circ} \mathrm{C}$. The DNA pellet was resuspended in 10 to $15 \mu \mathrm{l}$ of sterile distilled water $\left(\mathrm{dH}_{2} \mathrm{O}\right)$ and stored at $-20^{\circ} \mathrm{C}$.

PCR. We extracted $1 \mu \mathrm{l}$ of sample DNA from the paraffin tissues to use as a template for the PCR. Primers designed from a section of the EHNV genome by Gould et al. (1995) were used to amplify BIV: 5'GATCCACACGGCCTGACACCG-3', 5'-GATCCGAAAGACAGCAGCGGTCGA-3'. These primers produced a product of $218 \mathrm{bp}$ when used with a BIV template (authors' unpubl. data). The following PCR protocol was used: $10 \mathrm{pmol}$ per $25 \mu \mathrm{l}$ reaction tube of primers, $1.5 \mathrm{mM} \mathrm{MgCl}_{2}, 200 \mu \mathrm{M} \mathrm{dNTP}, 2.5 \mathrm{U}$ Taq polymerase. PCR program: $95^{\circ} \mathrm{C} \times 1 \mathrm{~min}, 35 \times\left(95^{\circ} \mathrm{C} \times\right.$ $\left.1 \mathrm{~min}, 62^{\circ} \mathrm{C} \times 1 \mathrm{~min}, 72^{\circ} \mathrm{C} \times 1 \mathrm{~min}\right), 72^{\circ} \mathrm{C} \times 5 \mathrm{~min}$. Probes were constructed by labelling the PCR product with digoxigenin (Boehringer Mannheim, Australia), for use in dot-blot hybridisation.

Dot blot with digoxigenin-labelled probes. We dotted $2 \mu \mathrm{l}$ of heat-denatured PCR product onto a positively charged nylon membrane. Hybridisation and detection protocols for digoxigenin-labelled probes were based on the manufacturer's specifications (Boehringer Mannheim, Australia). The nylon membrane was placed in a roller tube, prehybridisation buffer $(5 \times \mathrm{SSC}[750 \mathrm{mM} \mathrm{NaCl}, 75 \mathrm{mM}$ sodium citrate, adjust to $\mathrm{pH} 7.00], 1.0 \%$ [w/v] blocking reagent [Boehringer Mannheim], $0.1 \%$ N-laurolysarcosine, $0.02 \%$ SDS) was added and incubated for $1.5 \mathrm{~h}$ at $68^{\circ} \mathrm{C}$. Prehybridisation buffer was discarded; hybridisation buffer (labelled probe diluted in prehybridisation buffer) containing $10 \mathrm{ng} \mathrm{ml} l^{-1}$ of probe was added and incubated overnight at $68^{\circ} \mathrm{C}$. The probe was denatured prior to this by boiling for $10 \mathrm{~min}$. The membrane was washed for $2 \times 5$ min in $2 \times$ wash solution $(2 \times \mathrm{SSC}[300 \mathrm{mM} \mathrm{NaCl}, 30 \mathrm{mM}$ sodium citrate, adjust $\mathrm{pH} 7.00], 0.1 \%$ SDS), and $2 \times 15 \mathrm{~min}$ in $0.1 \times$ wash solution $(0.1 \times \mathrm{SSC}[15 \mathrm{mM} \mathrm{NaCl}, 1.5 \mathrm{mM}$ sodium citrate, adjust $\mathrm{pH} 7.00], 0.1 \% \mathrm{SDS}$ ) to remove unbound probe. All washes were performed in the roller tube at $68^{\circ} \mathrm{C}$.

The membrane was equilibrated in maleic acid buffer $(150 \mathrm{mM} \mathrm{NaCl}, 100 \mathrm{mM}$ maleic acid adjust to pH 7.5) for 1 min, then incubated in blocking buffer (1\% blocking reagent in maleic acid buffer) on a shaker for $30 \mathrm{~min}$. The membrane was then incubated on a shaker for $30 \mathrm{~min}$ in anti-digoxigenin conjugated to alkaline phosphatase diluted 1:5000 in blocking buffer. The membrane was washed $2 \times 15 \mathrm{~min}$ in maleic acid buffer on a shaker to remove unbound antibodies, and the substrate was then added. The membrane was equilibrated in developing buffer (100 mM Tris-HCl, pH 9.5, $100 \mathrm{mM} \mathrm{NaCl}, 50 \mathrm{mM}$ $\mathrm{MgCl}_{2}$ ) for $2 \mathrm{~min}$. Colour was developed by incubation in the dark in a solution consisting of $34 \mu \mathrm{l}$ of $100 \mathrm{mg}$ $\mathrm{ml}^{-1}$ nitroblue tetrazolium (NBT) salt in dimethylformamide, and $35 \mu \mathrm{l}$ of $50 \mathrm{mg} \mathrm{ml}^{-1}$ 5-bromo-4-chloro-3indolyl phosphate (BCIP) toluidinium salt in dimethylformamide added to $10 \mathrm{ml}$ of developing buffer at $37^{\circ} \mathrm{C}$.

\section{RESULTS}

\section{Litoria caerulea juveniles}

Cumulative mortalities for each of the viral challenge treatment groups are displayed in Fig. 1. High mortalities (20 frogs) occurred in the high-dose injection group within $11 \mathrm{~d}$ post-inoculation. Mortality

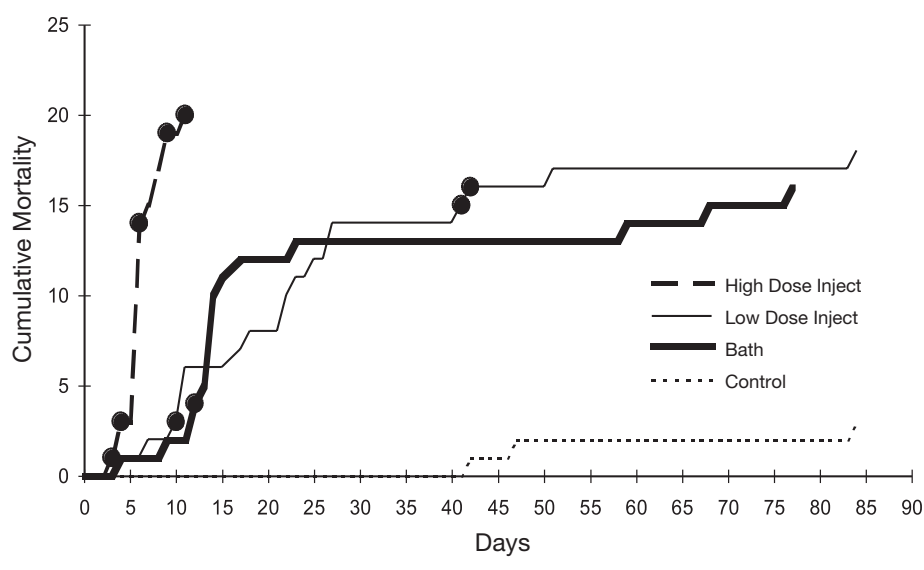

Fig. 1. Litoria caerulea. Cumulative mortality of juveniles challenged with Bohle iridovirus (BIV). • positive viral isolation 
patterns in the low-dose injection (18 frogs) and bath inoculation (16 frogs) groups were slower, and occurred predominantly within the first $25 \mathrm{~d}_{i} 3$ uninoculated control frogs died after Day 42 of the experiment. Some moribund frogs displayed a lack of response to stimuli, and failed to right themselves when overturned. Typically, the juveniles died with very few, if any, external signs. The experiment concluded $84 \mathrm{~d}$ post-challenge, at which time remaining frogs were sacrificed.

In the high-dose injection challenge, BIV was reisolated from frogs which died at 3, 4, 6, 9 and $11 \mathrm{~d}$ post-challenge (Fig. 1). BIV was reisolated from frogs which died 10, 41 and $42 \mathrm{~d}$ post-challenge in the low dose injection group, and from 1 frog which died $12 \mathrm{~d}$ post-challenge in the bath inoculation group.

Individuals in the BIV high-dose injection, low-dose injection and bath challenge treatments displayed classic BIV histopathology. Interstitial haematopoietic tissue in the kidney displayed focal areas of necrosis and nuclear pyknosis ranging from mild to extensive. Focal necrosis, margination of nuclear chromatin and pyknosis of nuclei of renal tubule cells was common. Glomeruli were sometimes shrunken and necrotic. Melanin was sometimes associated with necrotic lesions in haematopoietic tissue, tubules and glomeruli (Fig. 2). In the liver, lesions consisting of focal areas of hepatic cellular necrosis, margination of nuclear chro-

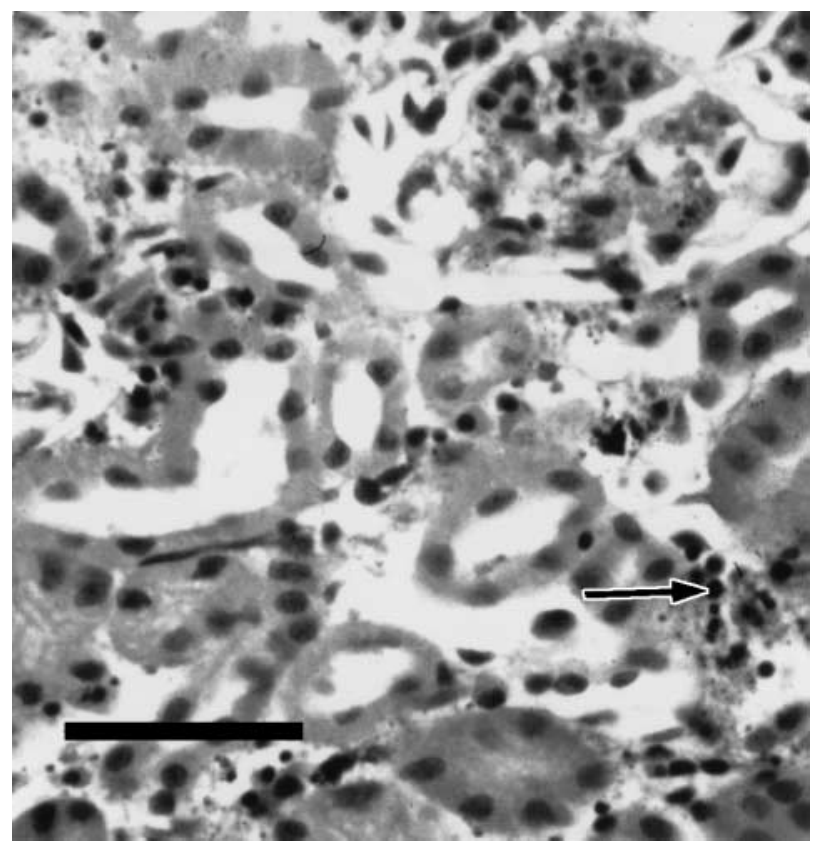

Fig. 2. Litoria caerulea. Kidney from a juvenile inoculated with Bohle iridovirus (BIV). Necroses of interstitial haematopoietic tissue and glomeruli are evident, arrow indicates pyknotic nucleus. H\&E stain. (Scale bar $=39 \mu \mathrm{m})$ matin and pyknosis of nuclei were common. Some areas of severe focal liquefying necrosis were noted. Lesions were sometimes associated with blood vessels. Lesions ranged from very small to extensive areas of cell destruction. Haemorrhages and melanin were often associated with the lesions. Hemosiderin deposition was also observed in some cases. Focal cellular necroses of splenic pulp with diffuse melanisation were observed. Lesions consisting of focal areas of cellular necrosis and pyknosis of nuclei were observed in pancreatic tissue (Fig. 3). Occasional very small areas of focal necrosis with associated melanisation were observed in the heart. Minor lung damage consisting of small focal areas of necrosis and melanisation within alveolar walls was occasionally observed. Focal areas of necrosis within the gastrointestinal mucosa were occasionally observed.

\section{Litoria caerulea adults}

No mortality occurred in any of the challenge or control treatments. BIV could not be isolated from any organs of any frog. No pathological changes could be observed in any organs upon histological examination.

\section{Litoria rubella adults}

None of the frogs displayed external disease signs or underwent mortality during the experiment. All the frogs were sacrificed $105 \mathrm{~d}$ post-challenge. All frogs were negative for BIV isolation, and no significant histopathological changes were observed in any of the frogs. One of the BIV-challenged frogs tested positive for the PCR and dot blot, while the other BIVchallenged frog and the unchallenged control frogs were negative.

Fig. 3. Litoria caerulea. Pancreas from a juvenile inoculated with Bohle iridovirus (BIV). An area of focal necrosis is evident. H\&E stain. $($ Scale bar $=31 \mu \mathrm{m})$

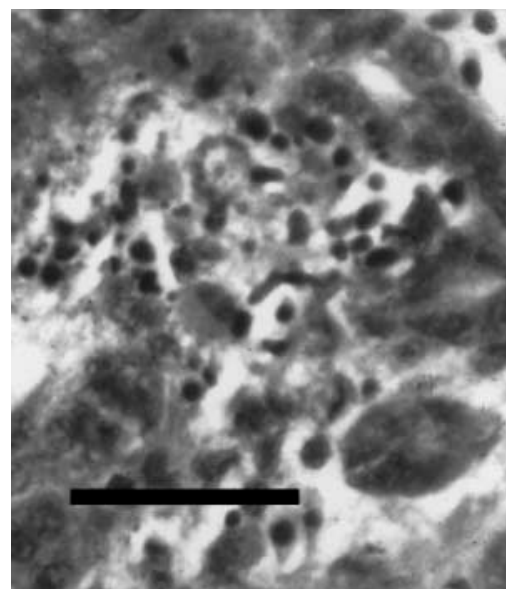




\section{Litoria inermis adults}

One of the BIV injection challenge frogs died $77 \mathrm{~d}$ post-challenge with no external signs. The control frog and the remaining BIV-injection challenge frog were sacrificed $92 \mathrm{~d}$ post-challenge, and showed no external signs of disease. All frogs were negative for BIV isolation. No significant histopathological findings were noted. Some post-mortem deterioration occurred in the BIV-injection challenge frog which died, so the histopathology was somewhat compromised. The 2 BIVchallenged frogs were both positive for the PCR and dot-blot test, while the unchallenged control frog was negative.

\section{Cophixalus ornatus adults}

One frog from the bath challenge treatment died $25 \mathrm{~d}$ post-challenge, but post-mortem changes were too extensive for the specimen to be of use histologically. BIV could not be isolated from any frogs in the challenge or control treatments.

\section{Taudactylus acutirostris adults}

One frog from the injection treatment died $1 \mathrm{~d}$ postinoculation and a further frog died $13 \mathrm{~d}$ post-inoculation $_{i} 1$ frog from the bath treatment died $12 \mathrm{~d}$ postchallenge. BIV could be isolated from the injected frog which died $13 \mathrm{~d}$ post-challenge, but not from any others. No significant histopathological changes could be observed; however the quality of the tissues was poor.

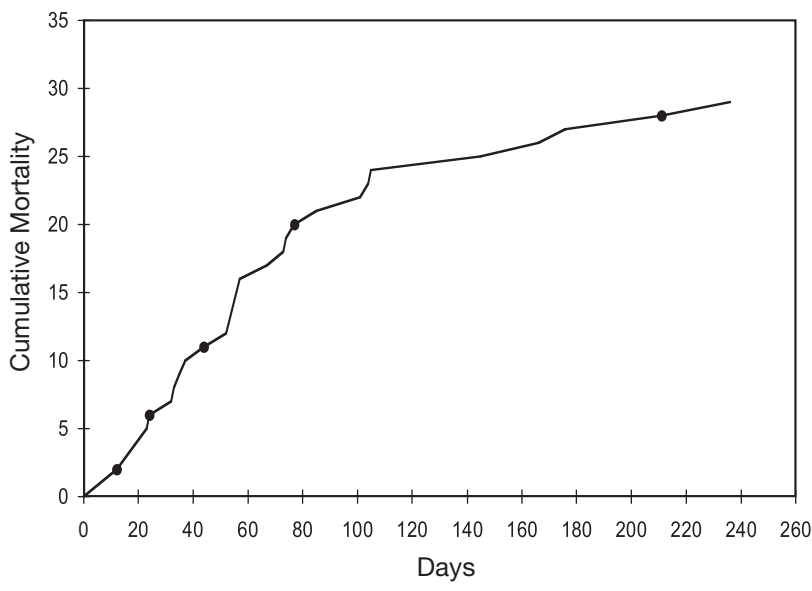

Fig. 4. Litoria alboguttata. Cumulative mortality of tadpoles and juveniles. $\bullet$ : positive viral isolation

211 and $236 \mathrm{~d}$ post-capture (Fig. 4). Positive results for viral isolation occurred in tadpoles which died 12, 24 and $44 \mathrm{~d}$ post-capture, and in juvenile frogs which died 77 and 211 d post-capture (Fig. 4).

Histopathologically, degeneration of renal tubules ranged from slight to extensive. Affected tubule cells often contained pyknotic nuclei, as did cells within some shrunken glomeruli. Some mild necrosis of interstitial haematopoietic tissue was encountered. Focal degeneration and necrosis of hepatic cells was observed, and was extensive in some frogs. Hepatic cell destruction was sometimes associated with a blood vessel or duct. Significant hemosiderin deposition was frequently seen in the spleen (Fig. 5), kidney, liver, and to a lesser extent the pancreas. Affected areas sometimes were associated with melanin.

\section{Litoria alboguttata tadpoles and juveniles}

Moribund tadpoles were sometimes found lying upside down on the bottom of the aquarium. When disturbed, they either righted themselves or swam in an erratic spinning motion. Juvenile frogs typically died with no external signs. All individuals succumbed to disease. This included 21 tadpoles; most of these died, but a small number were sacrificed when found in a moribund condition. A total of 8 tadpoles completed metamorphosis; subsequently all of these died. The snout-urostyle length of metamorphs ranged from 19 to $29 \mathrm{~mm}$. Moribund or dead tadpoles were found 12, $23,24,32,33,35,37,44,52,57,73,74,85$, 101 and 105 d post-capture. Dead juveniles were found $67,77,104,145,166,176$,

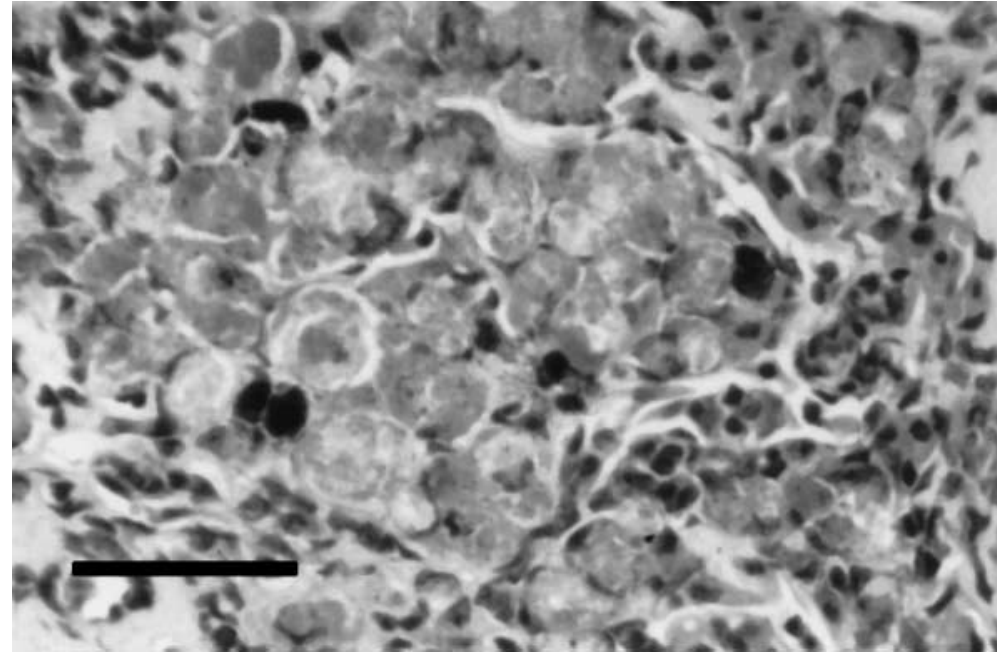

Fig. 5. Litoria alboguttata. Spleen from a juvenile that died from exposure to Bohle iridovirus (BIV). Large amounts of hemosiderin deposition are evident. H\&E stain. (Scale bar $=39 \mu \mathrm{m}$ ) 


\section{Cyclorana brevipes juveniles}

The 2 juvenile frogs died 5 and $11 \mathrm{~d}$ post-capture. Neither frog showed external signs of disease. The frog which died $11 \mathrm{~d}$ post-capture was positive for BIV isolation. The carcasses were not in a condition to yield satisfactory histopathology, so these individuals were not processed for histology.

\section{Moribund Litoria caerulea adult from Cranbrook}

The frog was in an emaciated state, sluggish and unresponsive to stimuli. Upon dissection, no fat bodies were evident. Massive hemosiderin deposition was evident throughout the liver. Scattered areas of melanisation were also present. The kidney was devoid of haematopoietic tissue. Hemosiderin was present in many of the tubule cells, and some tubule cells were granular with increased eosinophilia. The spleen contained areas of scar tissue, indicative of a previous lesion which had been resolved. A small amount of hemosiderin was also present. Some parasitic Rhabdias sp. nematodes were present in the lungs. The blood smear revealed numerous intraerythrocytic cytoplasmic gregarines. BIV could not be isolated in cell culture from any organs, but the frog was positive on PCR and dot blot.

\section{Pseudophryne coriacea juveniles}

Pseudophryne coriacea were raised from tadpoles collected in northern New South Wales in February 1994. After metamorphosis, they were housed in plastic tanks containing sand, leaves and bark. Water was provided, and they were fed Drosophila sp. A total of 9 frogs were housed in the tank. Eight months later, all frogs died over a period of $3 \mathrm{wk}$. Some of the frogs died suddenly with no apparent external signs. Other frogs showed lethargy, lack of co-ordination, a lack or slow response to stimuli, and difficulty in righting themselves if flipped over. All frogs were negative on viral isolation. The tissue architecture was compromised due to the frogs being frozen, so satisfactory histopathological observation could not be achieved. All frogs processed (6 total) were positive on PCR and dot blot.

\section{Odds ratio}

The odds of a juvenile frog dying as a result of BIV exposure as opposed to the odds of an adult frog dying as a result of BIV exposure was calculated as 66.64 (Table 2).
Table 2. Data from which odds ratio were calculated: odds ratio $=(68 \times 49) /(10 \times 5)=66.64$

\begin{tabular}{|lcc|}
\hline Stage & Frogs died (N) & Frogs survived (N) \\
\hline Juveniles & 68 & 10 \\
Adults & 5 & 49 \\
\hline
\end{tabular}

\section{DISCUSSION}

The disease and pathology of the BIV-challenged juvenile Litoria caerulea, and the juvenile $L$. alboguttata were similar to that seen in other amphibians (Cullen et al. 1995), fish (Moody \& Owens 1994) and reptiles (Ariel 1997). This included predominantly serious necroses of the renal tubules and haematopoietic tissues, splenic and hepatic tissues. Similar acute disease and pathologies have been reported in fishes and amphibians with other closely related ranaviruses, such as EHNV (Langdon \& Humphrey 1987, Langdon 1989), FV3 (Wolf et al. 1968, Granoff 1989), sheatfish iridovirus (Ogawa et al. 1990), catfish iridovirus (Pozet et al. 1992) and Rana temporaria iridovirus (Cunningham et al. 1996). The L. alboguttata also displayed a significant haemosiderosis, as did the adult $L$. caerulea from Cranbrook. This may be the major pathological sign observed in amphibians which develop a more chronic type of BIV disease, manifesting over a longer period than the acute disease observed in experimental challenge.

Some ranaviruses have a wide host range. Of fish species challenged experimentally with EHNV, some were highly susceptible while others were completely refractory (Langdon 1989). The effect of iridoviral disease on amphibian and piscine hosts often varies with the life history stage of the host. In many cases, juveniles tend to be more susceptible to disease than adults. BIV was largely consistent with this trend. Juvenile Litoria caerulea were highly susceptible to BIV, with an acute disease evident. Adult $L$. caerulea did not show disease signs $30 \mathrm{~d}$ post-challenge. Juvenile Bufo marinus showed typical acute disease and mortality when challenged with BIV, but adults were relatively resistant (Cullen 2000). Juvenile tortoises Emydura krefftii and Elseya latisternum were highly susceptible to BIV, whereas adults were resistant (Ariel 1997). Tadpole and juvenile $L$. alboguttata underwent a BIV epizootic, resulting in high mortality. Juvenile $L$. latopalmata and Limnodynastes terraereginae were highly susceptible, whereas tadpoles were less susceptible (Cullen et al. 1995). The Cyclorana brevipes which died 5 and $11 \mathrm{~d}$ post-capture were juveniles, as were the Pseudophryne corieacea from Sydney which underwent a Ranavirus sp.-associated mortality. The 
adult Litoria rubella challenged with BIV were resistant, with no mortality observed after $105 \mathrm{~d}$. Adult Cophixalus ornatus showed no disease $25 \mathrm{~d}$ after challenge with BIV, while some mortality was observed in adult Taudactylus acutirostris. The duration of experimental challenge must be taken into consideration when determining susceptibility. Some of the BIV challenges of adult amphibians were terminated at around $30 \mathrm{~d}$. Adult $L$. inermis were relatively resistant to BIV disease, but 1 frog did die $77 \mathrm{~d}$ post-challenge, and was positive on PCR and dot blot. The long-term effects of exposure to BIV in adult amphibians are still largely unknown.

The calculated odds ratio of 66.64 as the odds of a juvenile frog dying as a result of BIV exposure as opposed to the odds of an adult frog dying as a result of BIV exposure, indicated that juvenile amphibians had a considerably greater risk of dying from BIV than adults. It should be noted, however, that this data was taken across all amphibian species, and that the time frame over which the experimental infections took place was relatively limited.

Some amphibians exposed to BIV may survive infection and harbour the virus for extended periods. BIV could be reisolated from juvenile Litoria caerulea 41 and $42 \mathrm{~d}$ post-challenge. BIV was reisolated from tadpole $L$. alboguttata $32 \mathrm{~d}$, and in juveniles 65 and $199 \mathrm{~d}$ after the first mortalities were observed. BIV-challenged $L$. inermis tested positive by PCR and dot blot. One of these frogs died $77 \mathrm{~d}$ post-challenge, whilst the other was sacrificed $92 \mathrm{~d}$ post-challenge and had no signs of disease. One BIV-challenged L. rubella, which was sacrificed $105 \mathrm{~d}$ post-challenge with no signs of disease, tested positive by PCR and dot blot. The ability of BIV to remain in a host for extended periods would facilitate its continued spread and maintenance in the environment. Such hosts may be important viral reservoirs, promoting infection and mortality in susceptible hosts and, in juveniles, adversely affecting recruitment. BIV could be detected by PCR in individuals which showed no external signs of disease. This would make quarantine for BIV very difficult. With such a large demonstrated and potential host range, the means of transportation and spread of BIV, even intercontinentally, are numerous. There have been repeated examples of the development of subclinical iridoviral persistence and the presence of carrier hosts. Near-identical Ranavirus sp. isolates have been found throughout the world, and this may have been promoted by such a broad transmission regime.

PCR and dot blot has proved a useful tool in monitoring BIV. Viral isolation in cell culture is insensitive, and sometimes ambiguous. PCR is particularly useful in cases where the role of BIV is equivocal, where it is present in a host at low or subclinical levels, and where specimens are in poor condition. It is unlikely, however, to distinguish between different Ranavirus sp. isolates, and the PCR would detect closely related ranaviruses such as BIV, EHNV and FV3. The disease and mortality pattern observed in the Pseudophryne coriacea in Sydney was typical of BIV infection, and was similar to the mortality observed in Limnodynastes ornatus during its original isolation (Speare \& Smith 1992). Due to the specimens being frozen, histopathology was compromised, and the insensitive viral isolations were negative. The source of the ranaviral infection was unknown. The emaciated Litoria caerulea from Cranbrook also tested positive for PCR and dot blot. The major change observed was massive hemosiderin accumulations in the liver and kidney, similar to that associated with the L. alboguttata mortality. This may be an indication of anaemia. Anaemia has been associated with iridoviral infections of amphibians (Wolf et al. 1968, Granoff 1989, Gruia-Gray et al. 1989, Gruia-Gray \& Desser 1992) and fish (Evelyn \& Traxler 1978, MacMillan \& Mucahy 1979, Meyers et al. 1986, Armstrong \& Ferguson 1989, Haney et al. 1992, Inouye et al. 1992, Hetrick \& Hedrick 1993, Ahne 1994, Oshima et al. 1996, Nakajima et al. 1998). A characteristic of BIV infection is the destruction of haematopoietic tissues, which can result in anaemia. Rhabdias sp. and intraerythrocytic gregarines were present in this frog, but these are less likely to cause anaemia. BIV had only been isolated and associated with disease in wild-caught native Australian amphibians once. This was its initial isolation from Limnodynastes ornatus (Speare \& Smith 1992). The detection of ranaviruses associated with diseased amphibians from Sydney and Cranbrook is therefore significant. The viral source in each case was unknown, as was the particular Ranavirus sp. involved. Australian Ranavirus isolates currently consist of BIV isolated from amphibians in Townsville in 1989 (Speare \& Smith 1992), and EHNV, which was first isolated from fishes in Victoria in 1984 (Langdon et al. 1986), and later associated with fish epizootics of Victoria, New South Wales and South Australia (Langdon et al. 1986, Hengstberger et al. 1993, Whittington et al. 1994, 1996, Gould et al. 1995). The Australian ranaviruses are similar to other ranaviruses isolated on other continents, and the origin of the closely related ranaviruses remains to be elucidated.

Based on experimental data, BIV has the potential to have significant impacts on native Australian amphibian fauna. It can cause a serious, acute disease resulting in rapid mortality, particularly in juveniles. This may have an adverse affect on the recruitment of some amphibian populations. BIV had a differential susceptibility on amphibian hosts of different species and/or life history stage. Although adult amphibians appeared to be less susceptible to BIV over the experimental 
time period, some evidence exists to suggest the virus may still have been causing disease in the adult hosts, and the long-term effects of BIV are largely unknown. BIV can persist in an amphibian host for an extended time period. This, coupled with its ability to survive outside the host, particularly at lower temperatures, would facilitate the maintenance, transmission and transportation of BIV.

Acknowledgements. This work was funded by an Australian Postgraduate Research Award, and a Merit Research Grant, James Cook University.

\section{LITERATURE CITED}

Ahne W (1994) Viral infections of aquatic animals with special reference to Asian aquaculture. Annu Rev Fish Dis 1994: 375-388

Ahne W, Matasin Z, Bovo G (1995) Antigenic relationship of epizootic haematopoietic necrosis virus (EHNV) and iridovirus-like isolates from European green frogs (Rana esculenta). Bull Eur Assoc Fish Pathol 15:142-144

Ahne W, Bremont M, Hedrick RP, Hyatt AD, Whittington RJ (1997) Special topic review: iridoviruses associated with epizootic haematopoetic necrosis (EHN) in aquaculture. World J Microbiol Biotechnol 13:367-373

Ariel E (1997) Pathology and serological aspects of Bohle iridovirus infections in six selected water-associated reptiles in North Queensland. PhD thesis, James Cook University, Queensland

Ariel E, Owens L (1997) Epizootic mortalities in tilapia Oreochromis mossambicus. Dis Aquat Org 29:1-6

Armstrong RD, Ferguson HW (1989) Systemic viral disease of the chromide cichlid Etroplus maculatus. Dis Aquat Org $7: 155-157$

Clark HF, Brennan JC, Zeigel RF, Karzon DT (1968) Isolation and characterization of viruses from the kidneys of Rana pipiens with renal adenocarcinoma before and after passage in the red eft (Triturus viridescens). J Virol 2:629-640

Clark HF, Gray C, Fabian F, Zeigel R, Karzon DT (1969) Comparative studies of amphibian cytoplasmic virus strains isolated from the leopard frog, bullfrog and newt. In: Mizell M (ed) Biology of amphibian tumors, SpringerVerlag, Berlin, p 310-326

Cullen BR (2000) Bohle iridovirus and Ranavirus infection in amphibians. PhD thesis, James Cook University, Queensland

Cullen BR, Owens L, Whittington RJ (1995) Experimental infection of Australian anurans (Limnodynastes terraereginae and Litoria latopalmata) with Bohle iridovirus. Dis Aquat Org 23:83-92

Cunningham AA, Langton TES, Bennett PM, Lewin JF, Drury SEN, Gough RE, Macgregor SK (1996) Pathological and microbiological findings from incidents of unusual mortality of the common frog (Rana temporaria). Philos Trans R Soc Lond B Biol Sci 351:1539-1557

Drury SEN, Gough RE, Cunningham AA (1995) Isolation of an iridovirus-like agent from common frogs (Rana temporaria). Vet $\operatorname{Rec} 137: 72-73$

Eaton BT, Hyatt AD, Hengstberger S (1991) Epizootic haematopoietic necrosis virus: purification and classification. J Fish Dis 14:157-169

Elliot RM, Kelly DC (1980) Frog virus 3 replication-induction and intracellular distribution of polypeptides in infected cells. J Gen Virol 37:28-51

Essani K, Granoff A (1989a) Amphibian and piscine iridoviruses: proposal for nomenclature and taxonomy based on molecular and biological properties. Intervirology 30 : 187-193

Essani K, GranoffA (1989b) Properties of amphibian and piscine iridoviruses: a comparison. In: Ahne W, Kurstak E (eds) Viruses of lower vertebrates. Springer-Verlag, Berlin, $\mathrm{p} 79-85$

Evelyn TPT, Traxler GS (1978) Viral erythrocytic necrosis: natural occurrence in Pacific salmon and experimental transmission. J Fish Res Board Can 35:903-907

Flugel RM, Darai G, Gelderblom H (1982) Viral proteins and adenosine triphosphate phosphohydrolase activity of fish lymphocystis disease virus. Virology 122:48-55

Gould AR, Hyatt AD, Hengstberger SH, Whittington RJ, Coupar BEH (1995) A polymerase chain reaction (PCR) to detect epizootic haematopoietic necrosis virus and Bohle iridovirus. Dis Aquat Org 22:211-215

Granoff A (1989) Viruses of amphibia: an historical perspective. In: Ahne W, Kurstak E (eds) Viruses of lower vertebrates. Springer-Verlag, Berlin, p 3-12

Gruia-Gray J, Desser SS (1992) Cytopathological observations and epizootiology of frog erythrocytic virus in bullfrogs (Rana catesbeiana). J Wildl Dis 28:34-41

Gruia-Gray J, Petric M, Desser S (1989) Ultrastructural, biochemical and biophysical properties of an erythrocytic virus of frogs from Ontario, Canada. J Wildl Dis 25: 497-506

Haney DC, Hursh DA, Mix MC, Winton JR (1992) Physiological and hematological changes in chum salmon artificially infected with erythrocytic necrosis virus. J Aquat Anim Health 4:48-57

Hedrick RP, McDowell TS, Ahne W, Torhy C, deKinkelin P (1992) Properties of three iridovirus-like agents associated with systemic infections of fish. Dis Aquat Org 13:203-209

Hengstberger SG, Hyatt AD, Speare R, Coupar BEH (1993) Comparison of epizootic haematopoietic necrosis and Bohle iridoviruses, recently isolated Australian iridoviruses. Dis Aquat Org 15:93-107

Hetrick FM, Hedrick RP (1993) New viruses described in finfish from 1988-1992. Annu Rev Fish Dis 1993:187-207

Inouye K, Yamano K, Maeno Y, Nakajima K, Matsuoka M, Wada Y, Sorimachi M (1992) Iridovirus infection of cultured red sea bream, Pagrus major. Fish Pathol (Gyobyo Kenkyu) 27:19-27

Kanchanakhan S (1998) An ulcerative disease of the cultured tiger frog, Rana tigrina, in Thailand: virological examination. Newsl Aquat Anim Health Res Inst 7(2):1-2

Langdon JS (1989) Experimental transmission and pathogenicity of epizootic haematopoietic necrosis virus (EHNV) in redfin perch, Perca fluviatilis L., and 11 other teleosts. J Fish Dis 12:295-310

Langdon JS, Humphrey JD (1987) Epizootic haematopoietic necrosis, a new viral disease in redfin perch, Perca fluviatilis L., in Australia. J Fish Dis 10:289-297

Langdon JS, Humphrey JD, Williams LM, Hyatt AD, Westbury HA (1986) First virus isolation from Australian fish: an iridovirus-like pathogen from redfin perch, Perca fluviatilis L. J Fish Dis 9:263-268

MacMillan JR, Mulcahy D (1979) Artificial transmission to and susceptibility of Puget Sound fish to viral erythrocytic necrosis (VEN). J Fish Res Board Can 36:1097-1101

Mao J, Hedrick RP, Chinchar VG (1997) Molecular characterization, sequence analysis, and taxonomic position of newly isolated fish iridoviruses. Virology 229:212-220 
Meyers TR, Hauck AK, Blankenbeckler WD, Minicucci T (1986) First report of viral erythrocytic necrosis in Alaska, USA, associated with epizootic mortality in Pacific herring, Clupea harengus pallasi (Valenciennes). J Fish Dis 9:479-491

Moody NJG, Owens L (1994) Experimental demonstration of the pathogenicity of a frog virus, Bohle iridovirus, for a fish species, barramundi Lates calcarifer. Dis Aquat Org 18: 95-102

Nakajima K, Maeno Y, Yokoyama K, Kaji C, Manabe S (1998) Antigen analysis of red sea bream iridovirus and comparison with other fish iridoviruses. Fish Pathol 33:73-78

Ogawa M, Ahne W, Fischer-Scherl T, Hoffman RW, Schlotfeldt HJ (1990) Pathomorphological alterations in sheatfish fry Silurus glanis experimentally infected with an iridovirus-like agent. Dis Aquat Org 9:187-191

Oshima S, Hata J, Segawa C, Hirasawa N, Yamashita S (1996) A method for direct DNA amplification of uncharacterized DNA viruses and for development of a viral polymerase chain reaction assay: application to the red sea bream iridovirus. Anal Biochem 242:15-19

Pozet F, Morand M, Moussa A, Torhy C, deKinkelin P (1992) Isolation and preliminary characterization of a pathogenic icosahedral deoxyribovirus from the catfish Ictalurus melas. Dis Aquat Org 14:35-42

Speare R, Smith JR (1992) An iridovirus-like agent isolated from the ornate burrowing frog Limnodynastes ornatus in

Editorial responsibility: Pernel Zwart, Utrecht, The Netherlands northern Australia. Dis Aquat Org 14:51-57

Tapiovaara H, Olesen NJ, Linden J, Rimaila-Parnanen E, von Bonsdoff CH (1998) Isolation of an iridovirus from pikeperch Stizostedion luciopera. Dis Aquat Org 32:185-193

Whittington RJ, Philby A, Reddacliff GL, Macgown AR (1994) Epidemiology of epizootic haematopoietic necrosis virus (EHNV) infection in farmed rainbow trout, Oncorhynchus mykiss (Walbaum): findings based on virus isolation, antigen capture ELISA and serology. J Fish Dis 17:205-218

Whittington RJ, Kearns C, Hyatt AD, Hengstberger S, Rutzou $\mathrm{T}$ (1996) Spread of epizootic haematopoietic necrosis virus (EHNV) in redfin perch (Perca fluviatilis) in southern Australia. Aust Vet J 73:112-114

Willis DB, Goorha R, Miles M, Granoff A (1977) Macromolecular synthesis in cells infected by frog virus 3. VII. Transcriptional and post-transcriptional regulation of virus gene expression. J Virol 24:326-342

Willis DB, Goorha R, Chinchar VG (1985) Macromolecular synthesis in cells infected by frog virus 3. Curr Top Microbiol Immunol 116:77-106

Wolf K, Bullock GL, Dunbar CE, Quimby MC (1968) Tadpole edema virus: a viscerotropic pathogen for anuran amphibians. J Infect Dis 118:253-262

Zupanovic Z, Musso C, Lopez G, Louriero CL, Hyatt AD, Hengstbereger S, Robinson AJ (1998) Isolation and characterization of iridoviruses from the giant toad Bufo marinus in Venezuela. Dis Aquat Org 33:1-9

Submitted: September 30, 2000; Accepted: November 20, 2001 Proofs received from author(s): May 2, 2002 